\title{
The Integrity of Public Accountant has Implications for Detecting Fraud in Conducting an Audit
}

\author{
Ely Suhayati \\ Lecturer of Accounting Study Program \\ in the Faculty of Economics an Business \\ Universitas Komputer Indonesia \\ Bandung, Indonesia \\ ely.suhayati@email.unikom.ac.id
}

\begin{abstract}
This study has a purpose to find out how much the integrity of a public accountant has implications for detecting fraud in conducting an audit. It used Structural Equation Modeling as the research method with 30 Public Accountants from 10 Public Accounting Firms in Bandung City as the respondents. The integrity of public accountants has implications for detecting fraud in conducting an audit is $55.6 \%$. Integrity is absolutely required by a public accountant in conducting an audit, because the honest and firm public accountant can detect fraud in conducting an audit, besides that the public accountant will not want to be compromised to do fraudulently. Integrity is not only absolutely needed by a public accountant in the public accounting firm, but for all accountants in various fields, especially in the government scope.
\end{abstract}

Keywords - integrity, public accountant, public accounting firm, detecting fraud, audit

\section{INTRODUCTION}

Reference [1] stated "The Influence of professional skepticism, ethics, personality type, competence and experience on fraud detection". Reference [2] stated Honesty is an important component from trust, without trust an organization cannot function properly, with the research entitled "Ethical behavior in the accounting profession, code of ethics of the accounting profession and ethics in auditing". Reference [3] stated skepticism has a positive influence on the auditor responsibility in detecting fraud with the research entitled "The influence of skepticism, independence, competence, auditor training and audit risk on the auditor responsibility in detecting fraud". Reference [4] stated "The reason auditors fail to detect fraud, one of which is a lack of evidence adequate ". Reference [5] stated The main key to designing an effective audit is to assess the identified risks, because the auditor can design, perform procedures that are effective for dealing with risk using intuition, experience and integrity. Reference [6] stated "Integrity can prevent fraud in Financial Statements".

The integrity of public accountant has implications for detecting fraud in conducting an audit. The audit of financial statements is an examination of financial statements by a Public Accountant. The reason for an entity conducting an audit of financial statements is to improve the quality of information in decision making But there are some of the problems concerning. references [7] stated "public accountants in conducting the audit process who are not successful in detecting errors in the financial statements, it is because of the low integrity of public accountants because they simply believe in the assertions without having supporting evidence that are given by the management."

Reference [8] stated "public accountants are required to have integrity, so they can uphold the character because the accounting profession is educated to behave honestly and firmly". Integrity, one of which is shown by examining the financial statements that have been prepared by the management along with accounting records and supporting evidence, therefore an accountant when carrying out his duties is very close to the flow of money. References [9] stated If they fiddle with financial records, they will find the transaction flow. For this reason, the profession must play a greater role. References [10] stated accountants always pay attention to details, the reason is that accountants always deal with Financial Statements so that it requires them to do everything in detail. The point is that accountants must account for the report so that there are demands that the report must be correct. Moreover accountants are usually educated to have great curiosity about the truth. It directs them to always be able to investigate the possibility of errors, fraud, procedural errors or the existence of illegal things in a report, so that they can detect fraud.

Because it examines more than one public accounting firm, while the type of data consists of primary data and secondary data. Primary data is collected using questionnaires and interviews, the statements in the questionnaire is in the form of a closed statement that has been provided an alternative answer by the author to be chosen by the respondent because the indicator to be measured is the clear indicator or it has been operationalized before. Secondary data for each variable is collected through literature studies, accounting magazines, research articles and journals. Furthermore, the data were analyzed using Structural Equation Modeling with Least Square 2.0 Partial Software. There were 30 Public Accountants from 10 Public Accounting Firms in the Bandung area as the Respondents. The observation unit in this study was a partners in a Public Accounting Firm.

\section{METHOD}

The method in this study is descriptive verificative, the data collection method is a survey method because it examines more than one public accounting firm, while the type of data consists of primary data and secondary data. Primary data is collected using questionnaires and interviews, the statements in the questionnaire is in the form of a closed statement that has been provided an alternative 
answer by the author to be chosen by the respondent because the indicator to be measured is the clear indicator or it has been operationalized before. Secondary data for each variable is collected through literature studies, accounting magazines, research articles and journals. Furthermore, the data were analyzed using Structural Equation Modeling with Least Square 2.0 Partial Software. There were 30 Public Accountants from 10 Public Accounting Firms in the Bandung area as the Respondents. The observation unit in

this study was a partners in a Public Accounting Firm.

\section{RESULTS}

Furthermore, in accordance with the purpose of the study, to test how much the Integrity of Public Accountant (X1) has implications for detecting fraud in conducting an Audit (Y).

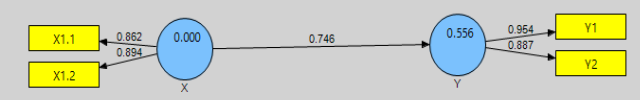

Fig.1.Full Model Path diagram

Through the factor weights that are shown in Figure 1, it can be seen in the integrity latent variable (X1), the X1.2 (Assertiveness) indicator is stronger in reflecting integrity latent variable than the X1.1 (Honesty) indicator, while detecting fraud in doing audit latent variable (Y), Y1 (audit planning) indicator is stronger in reflecting detecting fraud latent variables than $\mathrm{Y} 2$ (audit risk) indicator.

\section{Hypothesis Testing}

How big the Integrity of Public Accountant has implications for detecting fraud in conducting an audit

\begin{tabular}{|c|l|}
\hline $\mathrm{H}_{0}: \gamma_{1.1}=0$ & \multicolumn{1}{|c|}{$\begin{array}{c}\text { The integrity of the Public Accountant does } \\
\text { have implication for detecting fraud in } \\
\text { conducting } \\
\text { an audit at Public Accountant Firm in Bandung } \\
\text { City. }\end{array}$} \\
\hline $\mathrm{Ha}: \gamma_{1.1} \neq 0$ & $\begin{array}{l}\text { The integrity of Public Accountant has } \\
\text { implications for detecting fraud in conducting an } \\
\text { audit at Public Accountant Firm in Bandung } \\
\text { City. }\end{array}$ \\
\hline
\end{tabular}

TABLE I. STRUCTURAL EQUATIONS OF THE INTEGRITY OF PUBLIC ACCOUNTANT HAS IMPLICATIONS FOR DETECTING FRAUD IN CONDUCTING AN AUDIT

\begin{tabular}{|c|c|c|c|c|c|}
\hline $\begin{array}{c}\text { Latent } \\
\text { Variable }\end{array}$ & $\begin{array}{c}\text { Koefisien } \\
\text { Jalur }\end{array}$ & $\mathbf{T}_{\text {count }}$ & $\mathbf{T}_{\text {critical }}$ & Information & Conclution \\
\hline $\mathbf{X 1 ~ - > ~ Y ~}$ & 0.746 & 17.554 & 2.052 & Ho rejected & Significance \\
\hline
\end{tabular}

Table 1 : Tcount value is greater than Tcritical (1.96), so the error rate of $5 \%$ is decided to reject Ho so $\mathrm{Ha}$ is accepted.
Thus, it can be concluded that the integrity of public accountant has implications for detecting fraud in conducting an audit at Public Accountant Firm in Bandung City with $55.6 \%$

TABLE II. THE INTEGRITY OF PUBLIC ACCOUNTANT HAS IMPLICATIONS FOR DETECTING FRAUD IN CONDUCTING AN AUDIT

\begin{tabular}{|c|c|c|c|c|}
\hline \multirow{2}{*}{$\begin{array}{c}\text { Latent } \\
\text { Variable }\end{array}$} & $\begin{array}{c}\text { Koefisien } \\
\text { Jalur }\end{array}$ & $\begin{array}{c}\text { Direct } \\
\text { Influence }\end{array}$ & $\begin{array}{c}\text { Indirect } \\
\text { Influence }\end{array}$ & \multirow{2}{*}{ Total Influence } \\
& & $\mathbf{X}$ & \\
\hline X1 $>$ Y & 0.746 & 0.556 & - & 0.556 \\
\hline TOTAL & & & 0.556 \\
\hline
\end{tabular}

Table 2 : The relation between the integrity of Public Accountant in detecting fraud at the time of conducting an audit of 0.746 is in the interval $0.600-0.799$ which means it is strong.

\section{DISCUSSION}

Refences [11] stated To solve the problem of the low integrity of public accountants because they trust management assertions without being supported by evidence. References [12] stated "The auditor is responsible for detecting misstatements in the financial statements as a result of law violations, such as the auditor responsibility for errors and fraud in the financial statements. Although audit evidence and fraud can be obtained to provide adequate confidence, it does not mean that the material misstatement will be detected. The auditor is not responsible for planning and carrying out an audit in order to obtain confidence that misstatements are detected, whether caused by errors or fraud that are not material to the financial statements". Therefore, public accountants in conducting an audit need to be supported by sufficient competent evidence. For this reason integrity is needed, public accountants who have integrity have implications for detecting fraud in conducting an audit of $55.6 \%$ with a degree of closeness of $74.6 \%$.

References [13] stated the key factor that will play an important role for the success of the integrity of accountant services is education. References [14] stated Because since the beginning he has been educated to have an honest and firm attitude as professionals with high integrity, refences [15] stated an accountant will be an antidote to corruption actions. Professional accountants are not born but they are created meaning that competence and professionalism are not born by themselves, but through a long and continuous process. References [16] stated The problem becomes simpler because from the beginning a professional accountant has indeed been conditioned as a Business Leader with various competencies which are attached to him. References [17] stated an accountant is a profession, because in it there is a moral responsibility to keep up with work standards, uphold the integrity and professional ethics. References [18] stated an accountant is required to have an open mind, Out of The Box, and far ahead. Such thinking 
will bring professional accountants to remain dynamic and inline with the times.

\section{CONCLUSION}

The Integrity of Public Accountant has implications for detecting fraud in conducting an audit at Public Accountant Firm in Bandung City with a strong degree of closeness. References [19] stated "the crown of an accountant is integrity, he does not compromise on invitations to fraud, the accountant will be respected because accountant works always based on facts and rules and principles in accordance with standards, accountant does not want to be invited to compromise to cheat, so people will think twice to invite compromise, therefore do not be easily tempted do irregularities or fraud, accountant who has professionalism should uphold the profession".

\section{ACKNOWLEDGMENT}

This research is not possible with a good finish without the support of various parties, therefore, the authors thank the infinite and the highest appreciated to Assoc. Prof Dr. Ir. Eddy Soeryanto Soegoto MT As the Rector UNIKOM for the opportunity and support provided to follow ICOBEST that is one of the " Tridharma Perguruan Tinggi ".

\section{REFERENCES}

[1] Kadek Gita Arwinda Sari, Made Gede Wirakusuma dan Ni Made Dwi Ratnadi, "Pengaruh skeptisme profesional, etika, tipe pepribadian, kompetensi dan pengalaman pada pendeteksian kecurangan", ISSN : 2337-3067, e-Journal Ekonomi dan Bisnis, Universitas Udayana 7.1 (2018) : 29-56, 2018.

[2] Keyturn, "Perilaku etika dalam Profesi Akuntansi, Kode Etik Profesi Akuntansi dan Etika dalam Auditing", 14 November 2015

[3] Aviani Sanjaya, "Pengaruh Skeptisme, independen, kompetensi, pelatihan auditor dan resiko audit terhadap tanggungjawab auditor dalam mendeteksi kecurangan”, Jurnal Akuntansi Bisnis, Vol XV No. 30 Maret 2017.

[4] Stephen K. Asare, Arnie Wright \& Mark F. Zimbelman (2015) "Challenges Facing Auditors in Detecting Financial Statement Fraud : Insights from Fraud Investigations", Journal Of Forensic and Investigative Accounting Vol 7 Issue 2 July - December 2015.

[5] Michael Ramos, "Auditor's Responsibility For Fraud Detection", 1 January 2003.

[6] Norazida Mohamed, "Financial Statement Fraud Risk Mechanicms and Strategic The Case Studies of Malaysia Commercial Companies", Procedia-Social and Behavioral Sciences Vol 145, 25 August 2014, pages 321-329, 2014.

[7] Bapepam,"Keputusan Ketua Bapepam No kep 20/PM 2002 tertanggal 12 November 2002. Peraturan No. VII.A.2 tentang Independensi Akuntan yang memberikan jasa Audit di pasar Modal", Jakarta, 2002

[8] Anies Baswedan,"Menentang Masa Depan”, Majalah Akuntan, Desember, hal 12-13, 2014

[9] Amien Sunaryadi M.PA CISA.,Ak.,CA "Dorong Akuntan Lebih Berani Ungkap Korupsi”, Majalah Akuntan, Maret-April, halaman 31, 2015.

[10] Djoko Susanto,“Akuntan Lebih Siap Untuk memimpin”, Majalah Akuntan, Januari, hal 10, 2014.

[11] Ahmad Subianto, “Bisnis Indonesia,' 2006.

[12] Siti Kurnia Rahayu dan Ely Suhayati. “Auditing Konsep Dasar Dan Pedoman Pemeriksaan Akuntan Publik," Jakarta: Graha Ilmu, 2010.

[13] Sidharta Utama CA, "Peran Penting Profesi Pasca MRA, Majalah Akuntan, July-Agustus, Hal 35, 2014

[14] Mardiasmo,“Akuntan Lebih Siap Untuk memimpin”, Majalah Akuntan, Januari, hal 8, 2014.

[15] Ainun Naim.,CA, “Optimalkan Regenerasi Profesi”, Majalah Akuntan, Desember, Hal 14

[16] Panutan Sulendra Kusuma, "Kepemimpinan Akuntan masa Depan”, Majalah Akuntan Desember, hal 21, 2014.

[17] Sudirman Said MBA.,Ak.,CA, "Ruh Akuntan adalah Profesi," Majalah Akuntan, Desember, Hal 34.

[18] Ignatius Jonan.,MBA.,CPA.,CA, “ Akuntan harus Berpikir Broad Minded", Majalah Akuntan, Desember, Halaman 36, 2014.

[19] Soedarjono, Ak.,CA, "Jangan Terjebak Arogansi Profesi”, Majalah Akuntan, Januari, Hal 12, 2014. 